\title{
Pengembangan Sistem Informasi Asosiasi Jasa Konstruksi dengan Menerapkan Tanda Tangan Digital
}

\author{
http://dx.doi.org/10.28932/jutisi.v7i1.3431 \\ Riwayat Artikel \\ Received: 22 Februari 2021 | Final Revision: 8 Maret 2021 | Accepted: 12 Maret 2021

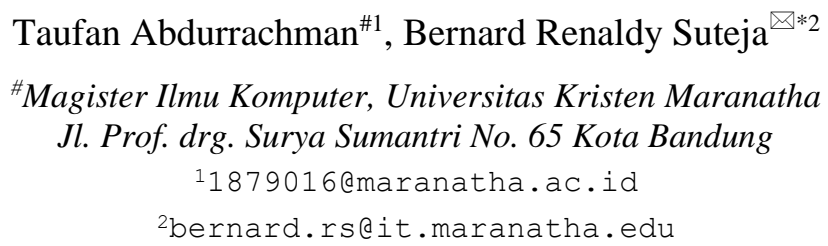

Abstract - Currently, the Indonesian government is changing the government system into a Sistem Pemerintahan Berbasis Elektronik (SPBE) or often heard as e-government. With this change in the government system, it has an impact on the various sector of life. One of many sectors is the construction service sector. Lembaga Pengembangan Jasa Konstruksi (LPJK) as a non-structural institution under the Ministry of Public Works and Public Housing issued a letter to the construction services association regarding the development of an integrated application with Sistem Informasi Konstruksi Indonesia (SIKI) LPJK. LPJK and Online Single Submission (OSS) institutions have implemented digital signatures on business entity licensing document. Construction service associations has responded to develop of these regulations by creating an association information system application that implements digital signatures. This research was conducted to apply a digital signature to the validation of the Certificate of Membership using the secure hash algorithm (SHA) and advanced encryption standard (AES) methods generated through the association information system. This application generates a digital signature which is implemented with QR Code. The existence of this application is expected to be a form of support for the government which is making changes to the government system.

Keywords - Advanced Encryption Standard; Digital Signature; Secure Hash Algorithm; E-Government.

\section{Pendahuluan}

Dewasa ini pesatnya perkembangan dalam bidang teknologi informasi dan komunikasi telah mempengaruhi segala aspek kehidupan, salah satunya mendorong pemerintah untuk berinovasi dalam mewujudkan tata kelola pemerintahan yang bersih, efektif, efisien, transparan, dan akuntabel. Saat ini pemerintah Indonesia sedang melakukan perubahan sistem pemerintahan dari sistem pemerintahan konvensional menjadi Sistem Pemerintahan Berbasis Elektronik (SPBE) atau sering dikenal dengan istilah $e$ government.

Untuk mendukung perkembangan dan pemanfaatan dalam bidang teknologi informasi dan komunikasi, pemerintah telah mengeluarkan beberapa peraturan yang bertujuan untuk mengatur dan memberikan rasa aman kepada pihak-pihak yang memanfaatkan perkembangan teknologi tersebut. Adapun peraturan yang telah dikeluarkan untuk menyikapi perkembangan teknologi informasi dan komunikasi sebagai berikut[1][2][3][4]:

- Undang-Undang Nomor 11 Tahun 2008, tentang Informasi dan Transaksi Elektronik

- Peraturan Pemerintah Nomor 82 Tahun 2012, tentang Penyelenggaraan Sistem dan Transaksi Elektronik

- Undang-Undang Nomor 19 Tahun 2016, tentang Perubahan Undang-Undang Informasi dan Transaksi Elektronik

- Peraturan Pemerintah Nomor 71 Tahun 2019, tentang Penyelenggaraan Sistem dan Transaksi Elektronik

Sedangkan untuk mengatur penerapan SPBE, pemerintah telah mengelurakan Peraturan Presiden Nomor 95 Tahun 2018, tentang Sistem Pemerintahan Berbasis Elektronik[5].

Untuk para pelaku usaha mulai usaha mikro, kecil, menengah maupun besar, usaha perorangan maupun badan usaha, baik yang baru maupun yang telah lama berdiri, dalam mengurus perizinan berusaha saat ini dapat memanfaatkan Online Single Submission (OSS). Lembaga OSS merupakan lembaga pemerintah non kementerian yang menyelenggarakan urusan pemerintah pada bidang koordinasi penanaman modal. Hadirnya lembaga OSS ini didasari oleh diterbitkannya Peraturan Pemerintah (PP) Nomor 24 Tahun 2018, tentang Pelayanan Perizinan 
Berusaha Terintegrasi Secara Elektronik. Dokumen perizinan berusaha yang diterbitkan oleh Lembaga OSS dalam bentuk dokumen elektronik disertai dengan tanda tangan elektronik yang dikonversikan dalam bentuk $Q R$ Code[6].

Kementerian Pekerjaan Umum dan Perumahan Rakyat (PUPR) saat ini sedang membangun Sistem Informasi Jasa Konstruksi (SIJK) Terintegrasi. Lembaga Pengembangan Jasa Konstruksi (LPJK) yang merupakan lembaga non struktural yang berada di bawah dan bertanggung jawab kepada Menteri, dalam hal ini Menteri Pekerjaan Umum dan Perumahan Rakyat, LPJK menerbitkan Sertifikat Badan Usaha (SBU), Sertifikat Keahlian, dan Sertifikat Keterampilan yang dibutuhkan oleh para pelaku usaha pada sektor jasa konstruksi. Berdasarkan Surat Edaran (SE) Menteri PUPR Nomor 06/SE/M/2019, SBU, Sertifikat Keahlian, dan Sertifikat Keterampilan diterbitkan dalam bentuk elektronik, dihasilkan melalui aplikasi Sistem Informasi Konstruksi Indonesia (SIKI) berbasis web yang digunakan oleh LPJK. Sertifikat dalam bentuk elektronik yang diterbitkan oleh LPJK telah ditandatangani secara digital dan terdapat $Q R$ Code sebagai jalan untuk melakukan verifikasi keaslian sertifikat tersebut[7]. Hadirnya lembaga OSS dan SIJK terintegrasi ditengah-tengah para pelaku usaha khususnya pada sektor jasa konstruksi menunjukan keseriusan pemerintah dalam mewujudkan SPBE di Indonesia.

LPJK Nasional melalui surat nomor 1241UM/LPJKN/IX/2020 menghimbau kepada asosiasi yang bergerak pada sektor jasa konstruksi untuk menyiapkan sistem sertifikasi yang dapat terintegrasi dengan SIKI LPJK[8]. Asosiasi Kontraktor Ketenagalistrikan Indonesia (AKLINDO) merupakan salah satu dari 72 asosiasi badan usaha yang bergerak pada sektor jasa kontruksi, AKLINDO mewadahi sejumlah badan usaha yang bergerak pada sektor jasa konstruksi yang tersebar di seluruh wilayah Indonesia. AKLINDO menerbitkan Kartu Tanda Anggota (KTA) yang diberikan kepada badan usaha yang bergabung dengan AKLINDO, KTA ini dibutuhkan oleh badan usaha untuk proses pengajuan SBU di LPJK. Saat ini AKLINDO belum memiliki sistem informasi asosiasi yang dapat terintegrasi dengan SIKI LPJK.

Maka pada penelitian ini, dibangun sistem informasi asosiasi AKLINDO yang dapat terintegrasi dengan SIKI LPJK dan juga dapat menghasilkan KTA disertai dengan tanda tangan digital yang dikoversikan dalam bentuk $Q R$ Code dari sebuah nilai hasil enkripsi dengan metode AES dan SHA-2, sehingga KTA aman dari tindakan pemalsuan. Dengan adanya sistem informasi asosiasi yang terintegrasi dengan SIKI LPJK diharapkan juga menjadi suatu bentuk dukungan terhadap pemerintah dalam mewujudkan SPBE di Indonesia.

Beberapa permasalahan yang dikaji pada penelitian ini, yaitu sebagai berikut:
1) Bagaimana membuat sistem informasi asosiasi yang mengimplementasikan tanda tangan digital?

2) Bagaimana algoritma AES dan SHA-2 dapat bekerja sebagai metode keamanan pada KTA AKLINDO?

\section{KAJIAN TEORI}

\section{A. Sistem Informasi}

Kebutuhan akan sistem informasi pada asosiasi jasa konstruksi saat ini, mendorong asosiasi untuk membangun sistem informasi yang nantinya dapat terintegrasi dengan SIKI LPJK. Sistem informasi merupakan kombinasi antara perangkat lunak (software), perangkat keras (hardware), basis data (database), jaringan komputer dan komunikasi data serta pengguna (user), yang tersusun secara sistematis, saling terhubung untuk mengumpulkan, mengubah, menyimpan, memproses, dan menyebarkan informasi dalam suatu bentuk organisasi[9]. Sistem informasi asosiasi ini dibangun untuk menghasilkan informasi yang dibutuhkan secara terstruktur, sistem informasi asosiasi yang dibangun menghasilkan berupa suatu dokumen KTA yang telah disertai dengan tanda tangan digital dengan bentuk $Q R$ Code.

\section{B. Kriptografi}

Kekuatan dari suatu tanda tangan digital bergantung pada metode kriptografi yang digunakan. Kriptografi (Cryptography) merupakan suatu ilmu atau seni yang mempelajari bagaimana cara menyimpan pesan, data dan/atau informasi agar tetap aman saat dikirimkan tanpa mengalami gangguan dari pihak lain[10]. Kriptografi memiliki 4 prinsip fundamental, yaitu[11]:

- Kerahasiaan (Confidelity)

- Keutuhan Data (Data Integrity)

- Keotentikan (Authentication)

- Anti Penyangkalan (Non-Repudiation)

Salah satu prinsip fundamental dari kriptografi yang menjadi syarat utama dari tanda tangan digital yaitu anti penyangkalan (non-repudiation) yang akan menjamin kebenaran dari suatu dokumen.

Fungsi yang mendasar dalam kriptografi yaitu enkripsi dan dekripsi. Enkripsi adalah proses penyandian untuk mengubah pesan atau teks asli yang mudah dimengerti (plaintext) menjadi teks atau pesan yang tidak dapat dimengetri (chipertext), sedangkan dekripsi adalah proses untuk mengubah chipertext menjadi sebuah pesan atau teks asli (plaintext).

Berdasarkan jenis kuncinya terdapat 2 (dua) jenis algoritma kriptografi, yaitu:

- Algoritma Kriptografi Simetris (Symmetric algorithms)

- Algoritma Kriptografi Asimetris (Asymmetric algorithms)

1) Algoritma Kriptografi Simetris: Biasa disebut algoritma kriptografi konvensional, merupakan algoritma yang menggunakan kunci yang sama untuk proses enkripsi dan proses dekripsinya. Contoh algoritma kriptografi simetris 
adalah RC2, RC4, RC5, RC5, IDEA, OTP, Twofish, Magenta, FEAL, SAFER, LOKI, CAST, GOST, A5, Kasumi, Blowfish, DES, AES, dan lain-lain[11][12]. Gambar 1 menunjukan penggunaan kunci yang sama untuk proses enkripsi dan proses dekripsi[13].

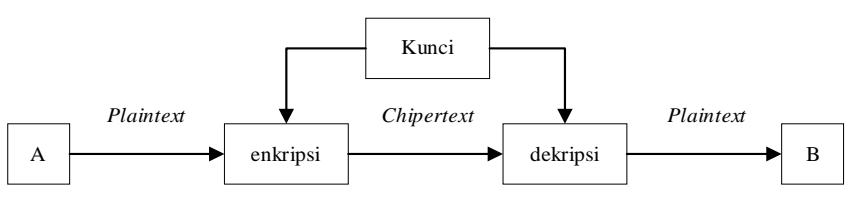

Gambar 1. Proses Kriptografi Simetris

2) Algoritma Kriptografi Asimetris: Dikenal sebagai algoritma kunci publik adalah algoritma yang menggunakan kunci yang berbeda untuk proses enkripsi dan proses dekripsinya. Pada algoritma ini kunci untuk proses enkripsi disebut dengan kunci publik (public key) sedangkan kunci untuk proses dekripsi disebut dengan kunci privat (private key). Contoh algoritma kriptografi asimetris adalah ECC, DH, Quantum, Rabin, ElGamal, DSA, RSA, dan lainlainnya[11][12]. Gambar 2 menunjukan penggunaan kunci yang berbeda untuk proses enkripsi dan proses dekripsi, kunci publik digunakan pada proses enkripsi sedangkan kunci rahasia digunakan pada proses dekripsi[13].

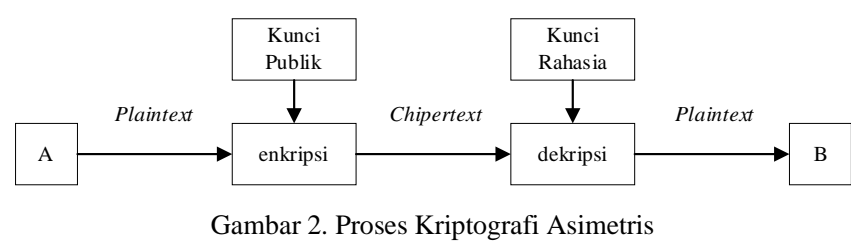

\section{Fungsi Hash}

Fungsi hash merupakan suatu fungsi yang menerima masukan berupa string yang memiliki panjang sembarang dan mengkonversi masukan tersebut menjadi string yang memiliki panjang tetap dan umumnya lebih kecil dari panjang semula. Keluaran dari suatu fungsi hash disebut dengan hash value atau pesan ringkas (message digest). Fungsi hash merupakan fungsi satu arah yang dapat menghasilkan ciri (signature) dari data. Adanya perubahan 1 (satu) bit saja akan mengubah keluaran hash secara drastis. Fungsi hash biasanya digunakan untuk menjamin integritas dan digital signature. Fungsi hash bekerja mengubah pesan asli menjadi sebuah message digest, message digest yang telah dihasilkan tidak dapat dikembalikan menjadi pesan asli kembali[13]. Tabel I. merupakan daftar algoritma fungsi hash.

TABEL I

DAFTAR AlgORITMA FungSi HASH[13]

\begin{tabular}{|l|l|l|l|l|l|l|}
\hline \multicolumn{1}{|c|}{ Algoritma } & \multicolumn{1}{|c|}{ Output size } & \multicolumn{1}{c|}{$\begin{array}{c}\text { Internal state } \\
\text { size }\end{array}$} & $\begin{array}{c}\text { Blok } \\
\text { Size }\end{array}$ & $\begin{array}{c}\text { Length } \\
\text { Size }\end{array}$ & \multicolumn{1}{|c|}{$\begin{array}{c}\text { Word } \\
\text { Size }\end{array}$} & \multicolumn{1}{c|}{ Collision } \\
\hline HAVAL & $256 / 224 / 192 / 160 / 128$ & 256 & 1024 & 64 & 32 & Yes \\
\hline MD2 & 128 & 384 & 128 & No & 8 & Almost \\
\hline MD4 & 128 & 128 & 512 & 64 & 32 & Yes \\
\hline MD5 & 128 & 128 & 512 & 64 & 32 & Yes \\
\hline PANAMA & 256 & 8736 & 256 & No & 32 & With flaws \\
\hline RIPEMD & 128 & 128 & 512 & 64 & 32 & Yes \\
\hline RIPEMD-128/256 & $128 / 256$ & $128 / 256$ & 512 & 64 & 32 & No \\
\hline RIPEMD-160/320 & $160 / 320$ & $160 / 320$ & 512 & 64 & 32 & No \\
\hline SHA-0 & 160 & 160 & 512 & 64 & 32 & Yes \\
\hline SHA-1 & 160 & 160 & 512 & 64 & 32 & With flaws \\
\hline SHA-256/224 & $256 / 224$ & 256 & 512 & 64 & 32 & No \\
\hline SHA-512/384 & $512 / 384$ & 512 & 1024 & 128 & 64 & No \\
\hline Tiger(2)-192/160/128 & $192 / 160 / 128$ & 192 & 512 & 64 & 64 & No \\
\hline VEST-4/8 & $160 / 256$ & $176 / 304$ & 8 & 80 & 1 & No \\
\hline VEST-16/32 & $320 / 512$ & $424 / 680$ & 8 & 88 & 1 & No \\
\hline WHIRLPOOL & 512 & 512 & 512 & 256 & 8 & No \\
\hline
\end{tabular}

1) Secure Hash Algorithm (SHA): Algoritma Secure Hash Algorithm (SHA) adalah salah satu fungsi hash kriptografi yang dirancang oleh National Security Agency (NSA) dan diterbitkan oleh National Institute of Standards and Technology (NIST) sebagai Federal Information
Processing Standards (FIPS) pada tahun 1993. Algoritma SHA dibuat berdasarkan fungsi hash MD4 dan desain modelnya menyerupai MD4[14]. Pada penelitian ini menggunakan SHA-256 yang akan menghasilkan message digest dengan panjang 256 bits. 


\section{Algoritma Advanced Encryption Standard (AES)}

Advanced Encryption Standard (AES) merupakan pengembangan dari algoritma Data Encryption Standard (DES). AES disosialisasikan sebagai sebuah standar ekripsi baru pengganti algoritma DES oleh National Institute of Standard and Technology (NIST)[15]. AES termasuk dalam algoritma block cipher yang memiliki sifat simetris, menggunakan kunci yang sama untuk proses enkripsi dan dekripsinya. AES memiliki panjang kunci yang beragam untuk mengenkripsi/ mendekripsi suatu blok berukuran 128 bit. Berdasakan panjang kuncinya, ada 3 (tiga) tipe AES, yaitu: AES-128 dengan panjang kunci 128 bit, AES-192 dengan panjang kunci 192 bit, dan AES-256 dengan panjang kunci 256 bit. Panjang kunci akan mempengaruhi jumlah putaran (round) pada proses enkripsi dan dekripsi[16]. Operasi algoritma AES secara garis besar untuk proses enkripsi adalah sebagai berikut[17]:

- AddRoundKey, yaitu melakukan XOR antara state awal (plaintext) dengan cipher key, tahap ini disebut initial round.

- Putaran sebanyak $N r-1$ kali. Proses yang dilakukan pada setiap putaran adalah:

a. Sub Bytes, yaitu subsitusi byte dengan menggunakan tabel subsitusi (S-box).

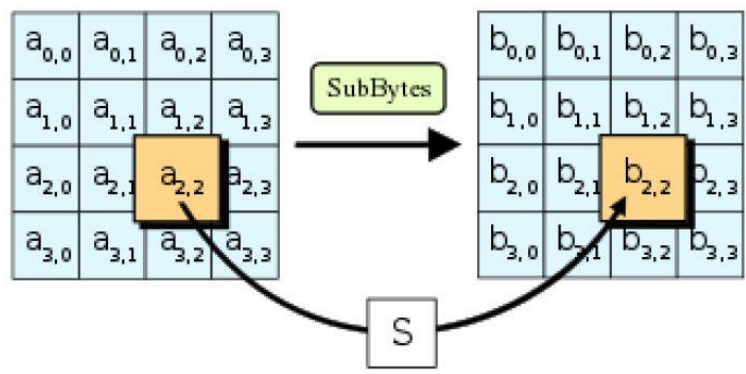

Gambar 3. Transformasi SubBytes dengan S-Box

b. ShiftRows, yaitu pergeseran baris-baris array state secara wrapping, byte di setiap baris dari state dialihkan putaran ke kiri.

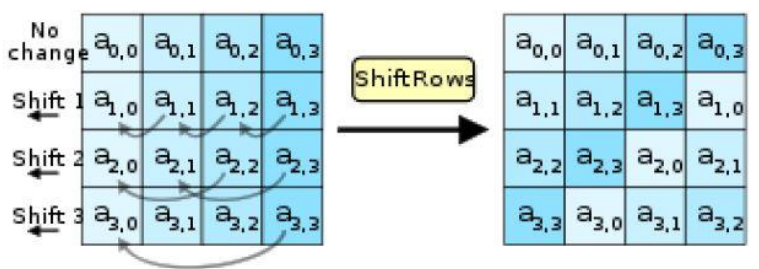

Gambar 4. ShiftRows

c. MixColumns, yaitu mengacak data di masingmasing kolom array state. Fungsi MixColumns mengambil empat byte sebagai masukan dan empat byte sebagai keluaran, di mana setiap masukan akan mempengaruhi semua keluaran.

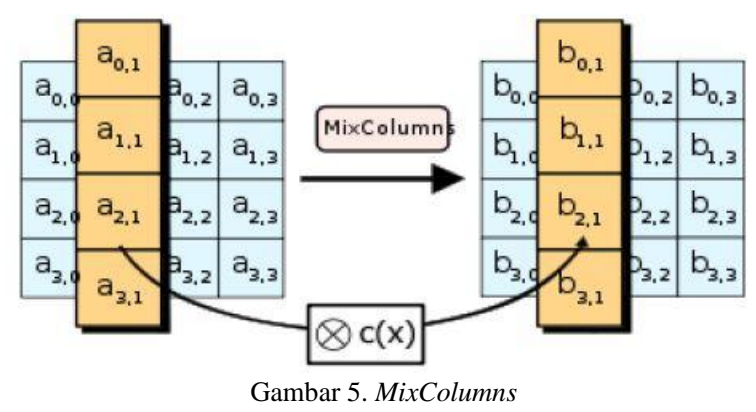

d. AddRoundKey, yaitu melakukan XOR antara array state saat ini dengan round key.

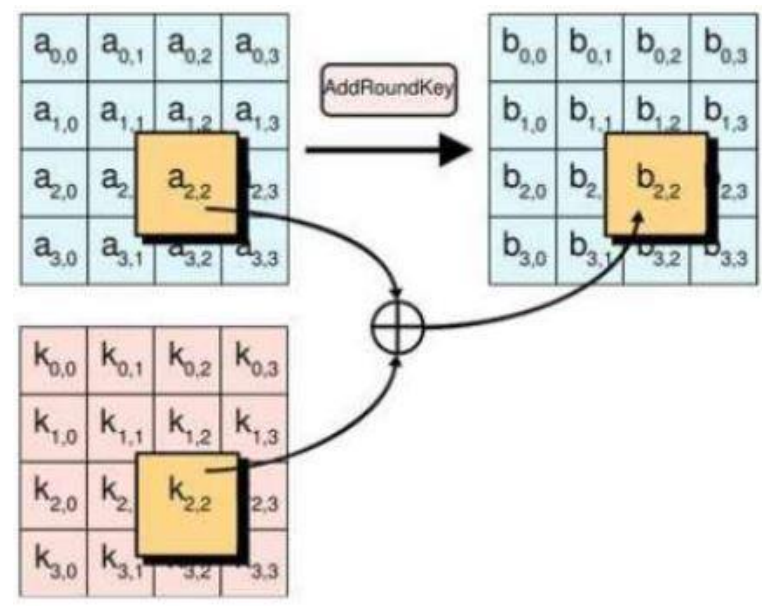

Gambar 6. AddRoundKey

- Final Round, yaitu proses putaran terakhir yang meliputi:

a. SubBytes

b. ShiftRows

c. AddRoundKey

Algoritma AES yang digunakan pada penelitian ini yaitu dengan panjang kunci 256 bit, dengan panjang kunci 256 bits maka terdapat sejumlah $2^{256}=1,16 \times 10^{77}$ kemungkinan kunci.

\section{E. QR Code}

Quick Response $(Q R)$ Code merupakan penyempurnaan dari barcode id yang dapat menyimpan lebih banyak informasi. $Q R$ code pertama kali digunakan pada industri otomotif di Jepang yang kemudian menjadi sangat popular karena keterbacaannya sangat cepat dan kapasitas penyimpanan lebih besar dibandingkan dengan kode UPC standar. $Q R$ code memiliki ukuran terkecil $21 \times 21$ modul dan ukuran terbesar 177x177 modul. $Q R$ code mempunyai 4 level koreksi kesalahan, yaitu: L, M, Q, H. Untuk kapasitas $Q R$ Code bergantung rgantung pada versi dan tingkat koreksi kesalahan, serta jenis data yang dapat dikodekan oleh $Q R$ Code ada 3, yaitu: numeric, alphanumeric, dan byte[18]. 


\section{TINJAUAN PUSTAKA}

Pemanfaatan tanda tangan digital untuk meningkatkan aspek keamanan terhadap suatu dokumen, khususnya dokumen penting seperti: ijazah, transkrip, sertifikat keterampilan/ keahlian, sertifikat badan usaha, surat perizinan dan lainnya dipandang perlu. Terdapat beberapa penelitian terdahulu yang mendukung dalam penelitian mengenai pemanfaatan tanda tangan digital ini.

Menurut Maykin dan Pramote dalam penelitiannya yang berjudul Paper-based Document Authentication using Digital Signature and $Q R$ Code, beberapa dokumen berbasis kertas seperti: dokumen akta kelahiran, sim, dan paspor yang masih belum dapat digantikan secara efisen dengan dokumen berbasis elektronik, sehingga masih dapat dengan mudah terjadinya penipuan. Dengan implementasi tanda tangan digital dan $Q R$ Code pada dokumen berbasis kertas, maka akan timbul integritas antara pesan teks pada dokumen dengan pembuat dokumen[19].

Menurut Aji dalam penelitiannya yang berjudul Pengembangan Aplikasi Pengaman Dokumen Digital Memanfaatkan Algoritma Advanced Encryption Standard, RSA Digital Signature dan Invisible Watermarking, kemudahan dalam mendistribusikan dokumen melalui media komunikasi elektronik menimbulkan suatu kerentanan berupa penduplikasian dan publikasi dokumen tanpa seizin dari pemilik dokumen tersebut. Walaupun digitalisasi dokumen merupakan suatu kebutuhan, perlu dipikirkan juga apsek keamanannya. Kriptografi menjadi salah satu solusi untuk mengamankan dokumen digital, memanfaatkan algoritma AES untuk melindungi saat proses distribusi dokumen dan algoritma RSA Digital Signature untuk menjamin otentikasi pengirim dan penerima dokumen yang memberikan layanan non-repudiation [17].

Ankit dan Pavithr dalam penelitiannya yang berjudul Degree Certificate Authentication using $Q R$ Code and Smartphone, membuat sistem yang menghasilkan sertifikat gelar yang dapat diverifikasi menggunakan $Q R$ Code melalui aplikasi smartphone. QR Code berisikan tanda tangan digital dari otoritas institusi pendidikan. Sistem ini dibuat untuk mencegah pembuatan sertifikat gelar palus di institusi pendidikan[18].

Abdul dan Abdul dalam penelitiannya yang berjudul Tanda Tangan Digital Menggunakan $Q R$ Code dengan Metode Advanced Encryption Standard, membuat sistem yang menerapkan tanda tangan digital pada dokumen pengambilan barang. Tanda tangan digital berfungsi sebagai otentikasi tanda tangan pimpinan dan juga verifikasi dokumen pengambilan barang yang sah. Pada penelitian ini didapatkan akurasi klasifikasi $Q R$ Code menggunakan naüve bayes classifier sebesar $90 \%$ dengan precision positif sebesar $80 \%$ dan precision negatif sebesar 100\%[20].

Menurut Yusuf, Erwin, dan Dewa dalam penelitian yang berjudul Implementasi Algoritma Rivest Shamir Adleman (RSA) pada Tanda Tangan Digital, tanda tangan digital dapat digunakan untuk pembuktian secara matematis bahwa data tidak mengalami modifikasi secara ilegal[21].

Selanjutnya Fitri, Yoga, Dede, dan Imas dalam penelitian yang berjudul Implementasi Skema $Q R$-Code dan Digital Signature menggunakan Kombinasi Algoritma RSA dan AES untuk Penggunaan Data Sertifikat Elektronik, mengimplementasikan tanda tangan digital pada file sertifikat elektronik untuk kegiatan webinar dan kursus online. Tanda tangan digital pada file sertifikat elektronik ini memanfaatkan fungsi hashing SHA-3 dan super enkripsi kombinasi antara RSA dengan AES 128 mode operasi CBC. Tanda tangan digital disisipkan pada file sertifikat elektronik dengan skema $Q R$ Code. Penelitian ini mendapatkan waktu enkripsi dan dekripsi dibawah 0,1 mili detik, nilai entropi sebesar 4,96, dan juga nilai avalanche effect sebesar 40,61\% membuktikan perubahan kode chipertext sudah sangat acak[22].

\section{ANALISIS DAN RANCANGAN SISTEM}

Aplikasi sistem informasi asosiasi AKLINDO harus dapat menghasilkan KTA yang dilengkapi tanda tangan digital dengan menerapkan metode AES dan SHA-2. Pada penelitian ini, data yang digunakan adalah data badan usaha anggota AKLINDO Provinsi Jawa Barat. Data ini adalah data informasi umum mengenai badan usaha.

Pada tahap perancangan aplikasi sistem informasi asosiasi AKLINDO dimulai dari pembuatan flowchart proses bisnis, hak akses pengguna (user), perancangan use case diagram, perancangan user interface, flowchart enkripsi dan dekripsi dan basis data (database). Dalam penggunaannya, aplikasi sistem informasi asosiasi AKLINDO setiap pengguna memiliki hak akses yang berbeda-beda.

\section{A. Flowchart Proses Bisnis}

Gambar 6 menunjukan alur dari proses bisnis yang ada pada Asosiasi AKLINDO Provinsi Jawa Barat. 


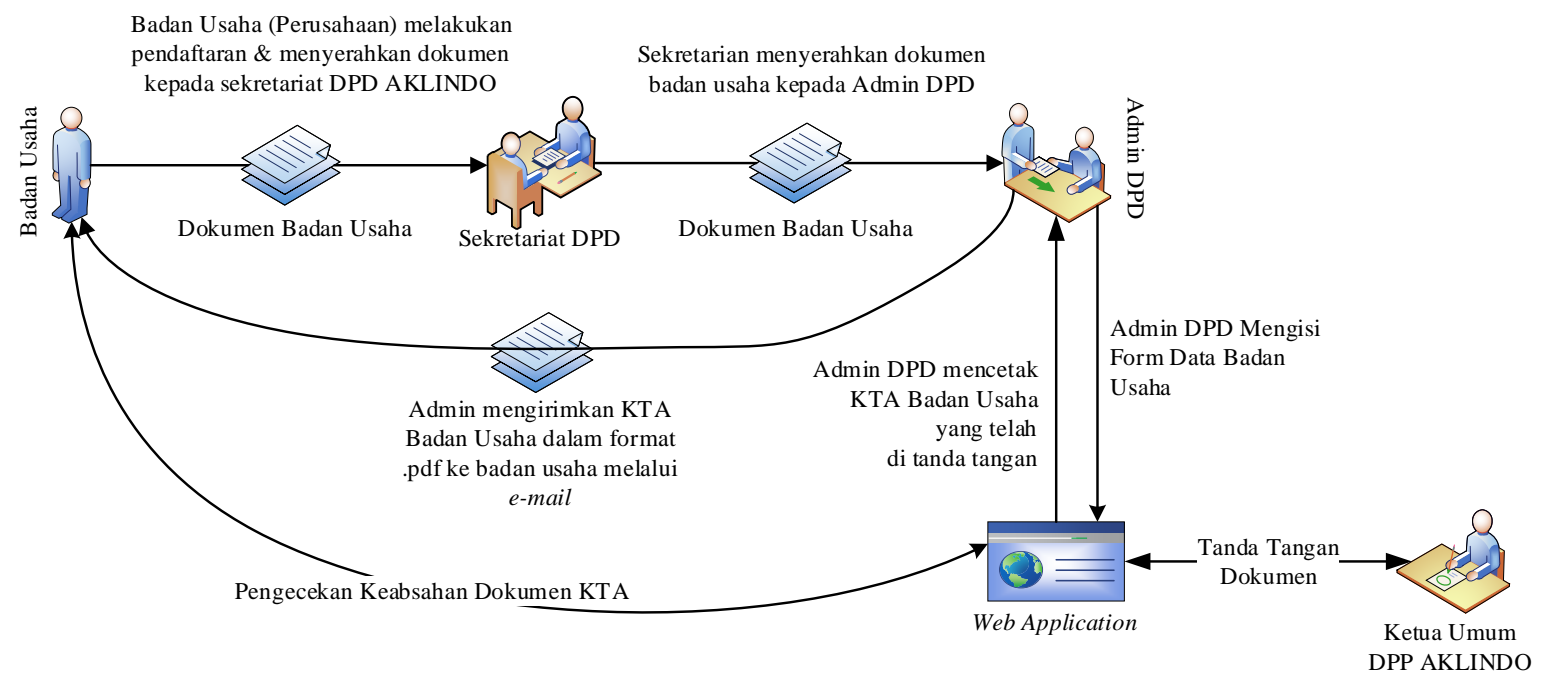

Gambar 6. Flowchart Proses Bisnis

\section{B. Use Case Diagram}

Pada aplikasi sistem informasi asosiasi AKLINDO, setiap pengguna (user) memiliki hak aksesnya tersendiri, hal ini digambarkan pada Gambar 7 Use Case Diagram. Admin pusat (superadmin) memiliki hak akses, seperti: tambah/ ubah/ hapus data pengguna (user), data bentuk badan usaha, data kualifikasi badan usaha, data DPC, data DPD, data provinsi, dan data kab/ kota. Untuk admin daerah (admin) memiliki hak akses, seperti: tambah/ ubah/ hapus data badan usaha, data bentuk KTA, data cetak KTA, dan verifikasi keabsahan KTA. Untuk pimpinan pusat memiliki hak akses, seperti: pengesahan KTA dan verifikasi keabsahan KTA. Sedangkan untuk pengguna badan usaha hanya memiliki hak akses untuk verifikasi keabsahan KTA.

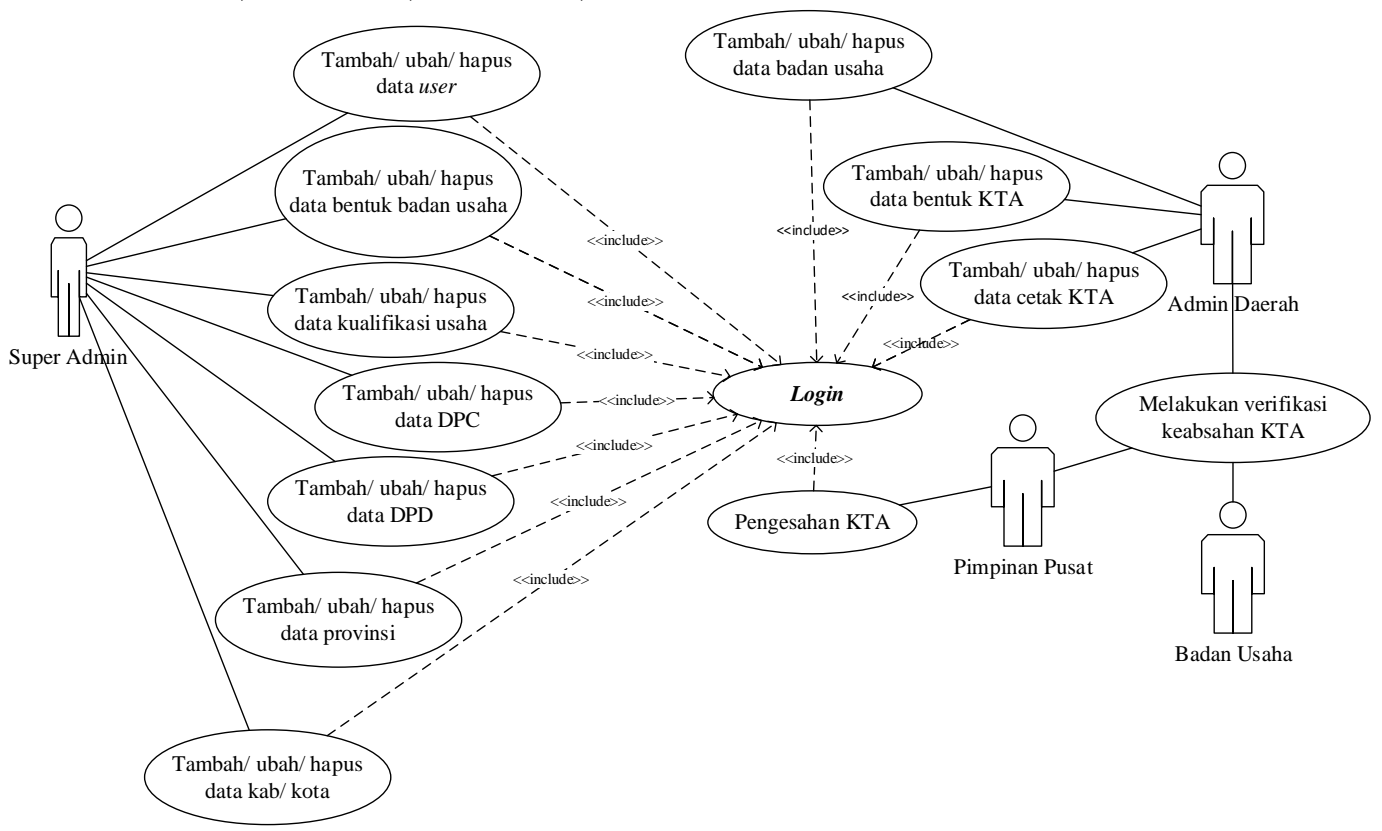

Gambar 7. Use Case Diagram Super Admin, Admin Daerah, Pimpinan Pusat, dan Badan Usaha

\section{Rancangan User Interface}

Berikut ini beberapa perancangan user interface pada aplikasi sistem informasi asosiasi yang telah dibangun seperti
Gambar 8 menggambarkan halaman login yang akan digunakan oleh setiap user. 


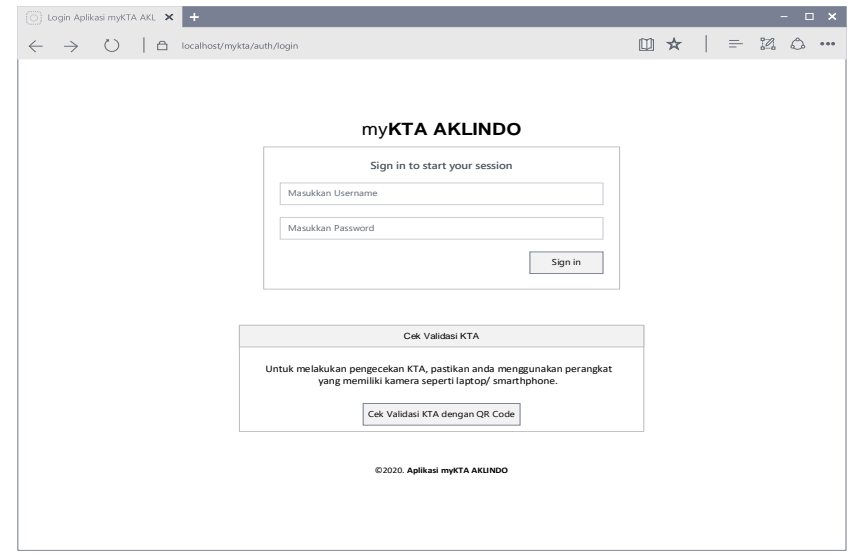

Gambar 8. Use Interface Login

Untuk Gambar 9 menggambarkan halaman dashboard ketika melakukan login sebagai superadmin, terdapat beberapa perbedaan hak akses pada masing-masing aku user.

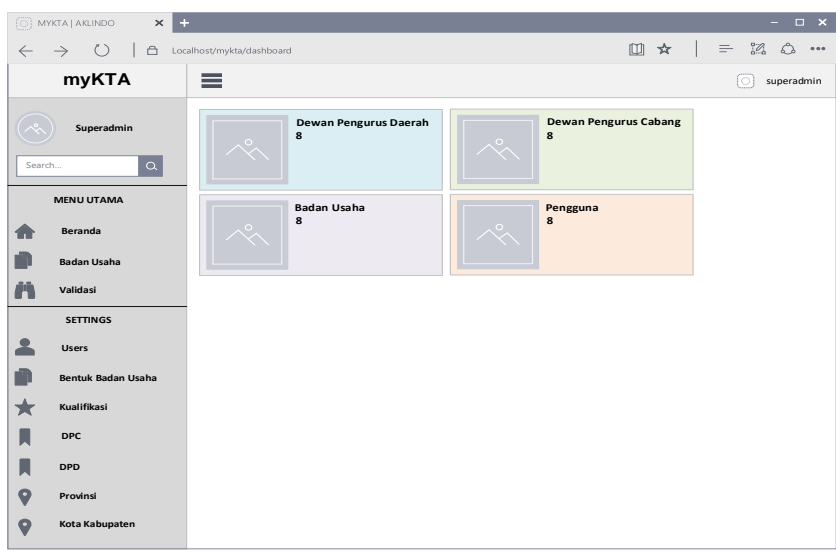

Gambar 9. Use Interface Dashboard Superadmin

Untuk Gambar 10 menggambarkan halaman tambah data badan usaha ketika user melakukan login sebagai admin.

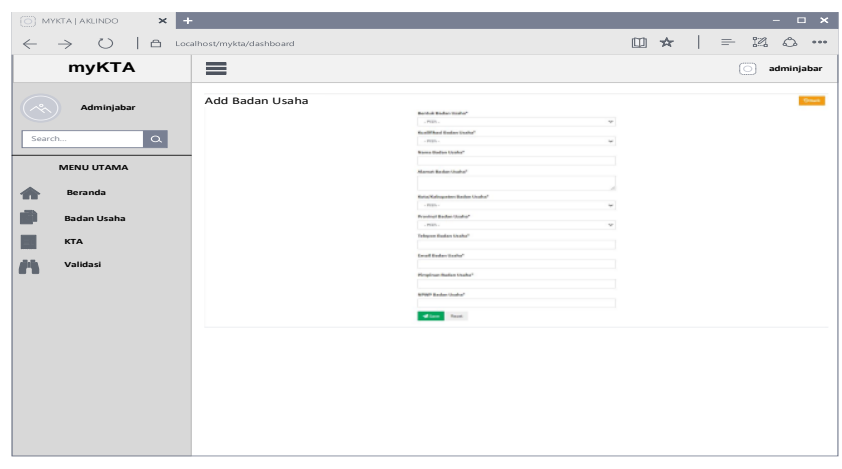

Gambar 10. Use Interface Tambah Badan Usaha
Pada Gambar 11 menggambarkan halaman menu pengesahan KTA yang hanya dapat di akses ketika user melakukan login sebagai pimpinanpusat.

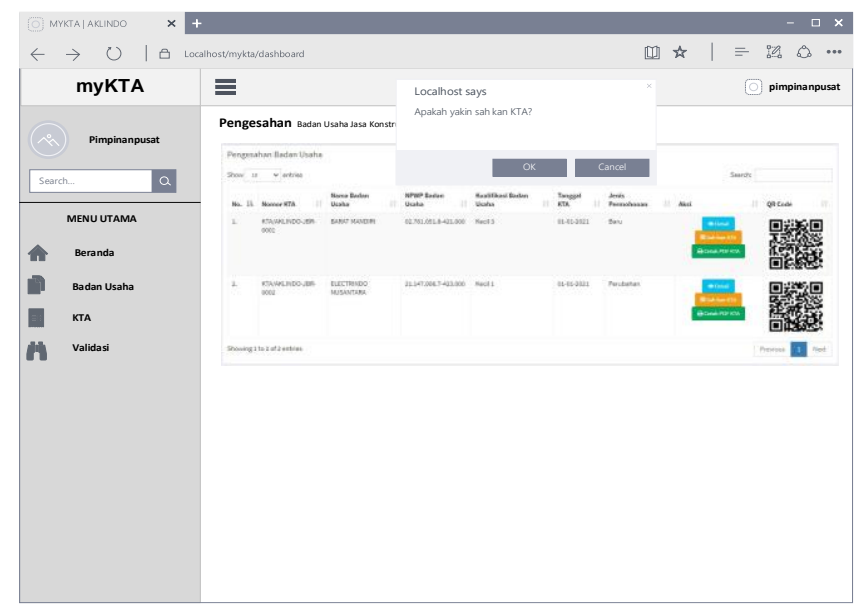

Gambar 11. Use Interface Menu Pengesahan KTA

Pada Gambar 12 menggambarkan halaman untuk validasi KTA.

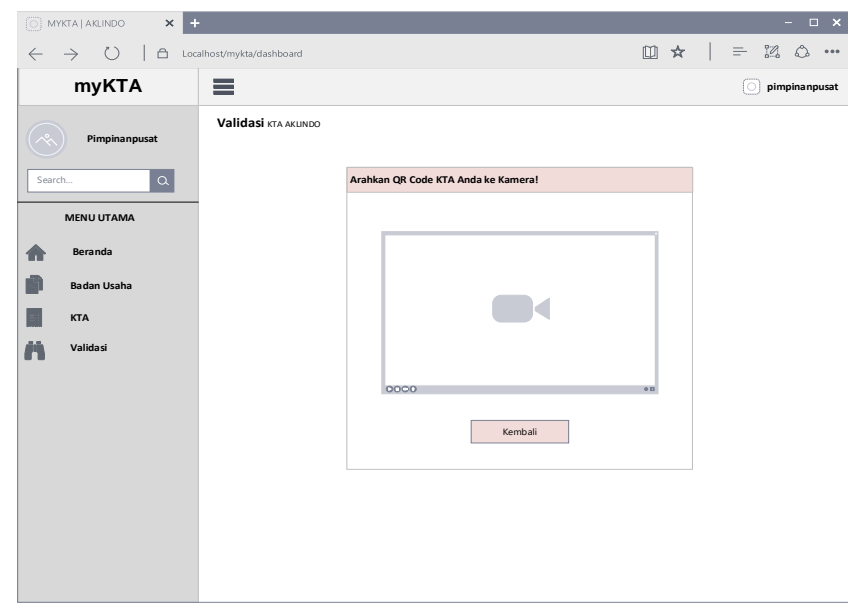

Gambar 12. Use Interface Validasi KTA

\section{Perancangan Basis Data}

Sistem informasi asosiasi AKLINDO ini menggunakan data dari asosiasi AKLINDO Provinsi Jawa Barat. Gambar 13 menunjukan hubungan antar tabel pada 1 (satu) database sistem informasi asosiasi AKLINDO, yang terdiri dari tabel user, tabel dpc, tabel dpd, tabel bentuk kta, tabel cetakkta, tabel badanusaha, tabel bentukbu, tabel kualifikasi, tabel kotkab, dan tabel provinsi. 


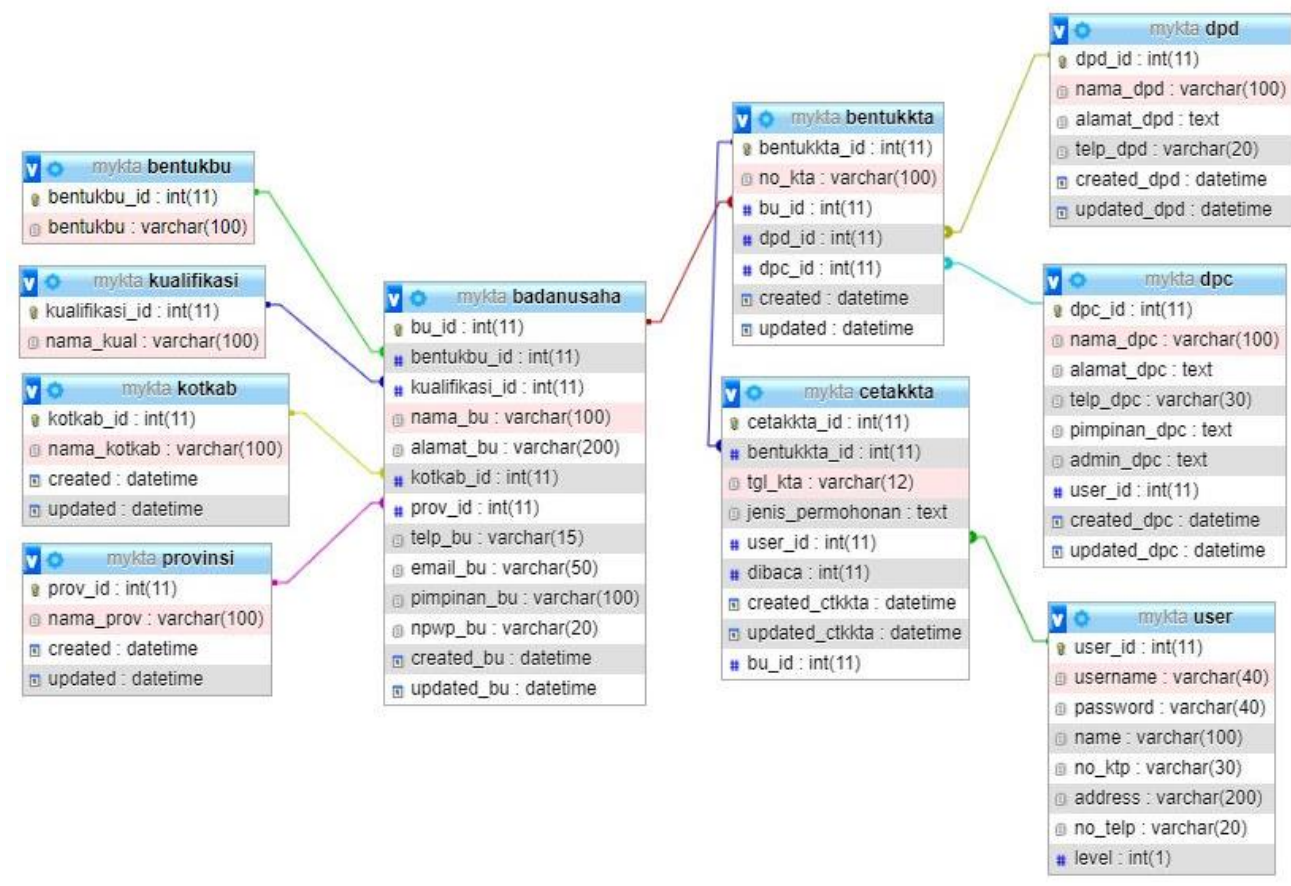

Gambar 13. Relasi Antara Table Database

\section{E. Perancangan Tanda Tangan Digital}

Dalam perancangan tanda tangan digital terdapat 2 (dua) proses utama, yaitu proses sign dan proses verify. Pertama pada proses sign, data akan melalui proses hashing menggunakan fungsi hash SHA-256, lalu akan mendapatkan nilai hash dari data. Selanjutnya message digest dari data masuk pada proses enkripsi menggunakan kunci privat dari algoritma AES. Pada proses enkripsi dengan AES ini akan dihasilkan kode tanda tangan digital, lalu dikonverikan menjadi $Q R$ Code melalui $Q R$ Code generator. Gambar $Q R$ Code yang dihasilkan lalu disisipkan pada dokumen KTA. Untuk proses verify dimana adalah kebalikan dari proses sign, maka $Q R$ Code akan terlebih dahulu dibaca menggunakan $Q R$ Code reader, lalu kode tanda tangan digital tersebut melewati proses dekripsi dengan AES, maka akan menghasilkan message digest.

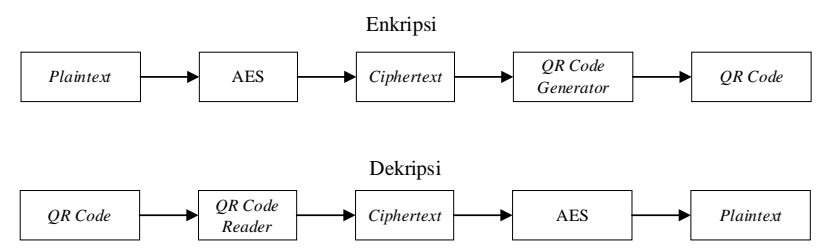

Gambar 14. Proses Enkripsi dan Dekripsi

\section{HASIL PENELITIAN DAN EVALUASI}

\section{A. Hasil Implementasi Perancangan}

Hasil dari perancangan sistem informasi asosiasi AKLINDO yang dibahas pada bab sebelumnya, menghasilkan sebuah sistem informasi asosiasi sebagai berikut: Gambar 15 menunjukan halaman form login yang digunakan oleh setiap user.

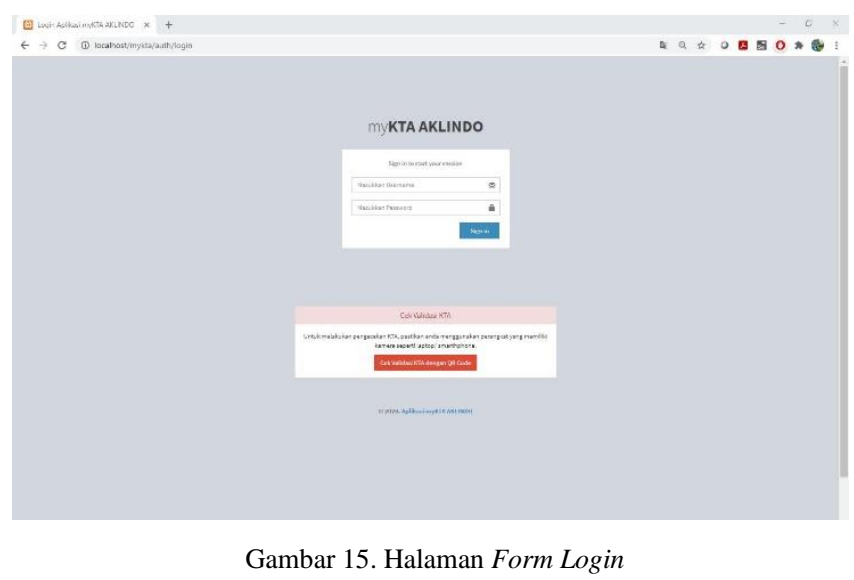

Selanjutnya pada Gambar 16 menunjukan halaman dashboard superadmin selaku admin pusat yang memiliki hak akses yaitu dapat melakukan aktivitas, penambahan, perubahan, dan penghapusan data, seperti: data users, data bentuk badan usaha, data kualifikasi, data DPC, data DPD, data provinsi, data kabupaten/ kota, cek validasi KTA dan melihat data badan usaha 


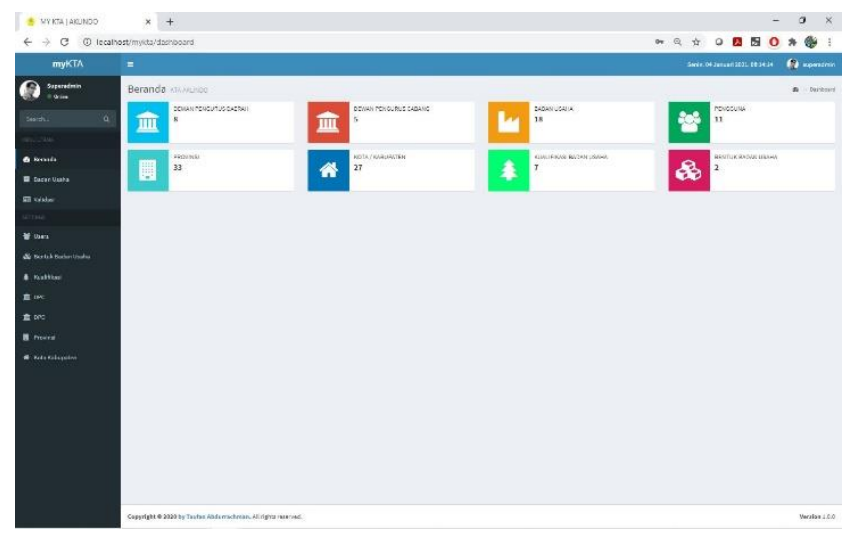

Gambar 16. Halaman Dashboard Superadmin

elanjutnya pada Gambar 17 menunjukan halaman tambah data badan usaha. User dengan status admin daerah (admin) dapat mengelola data yaitu menambah, mengubah, dan menghapus data, seperti: data badan usaha, data bentukkta, dan data cetakkta.

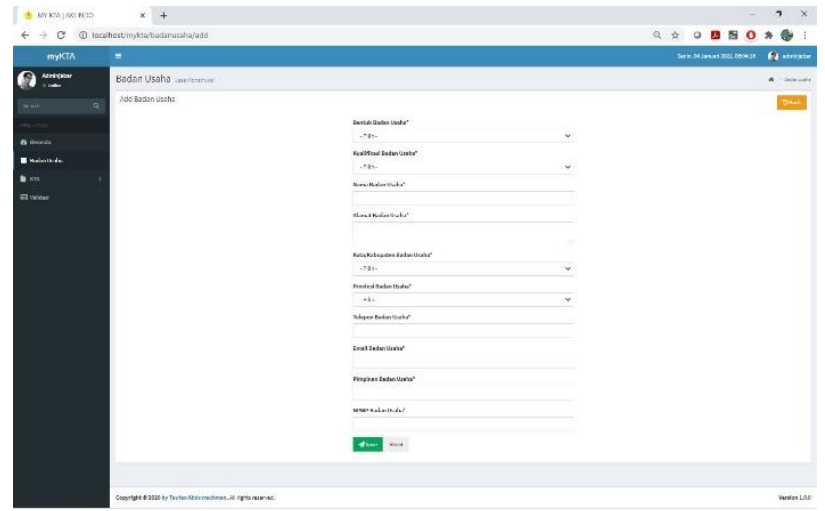

Gambar 17. Halaman Tambah Data Badan Usaha

Selanjutnya ketika user melakukan login sebagai pimpinan pusat, user dapat melakukan pengesahan KTA, melihat data pengesahan KTA dan melihat detail data KTA yang akan disahkan melalui halaman pengesahan KTA yang dapat dilihat pada Gambar 18 .

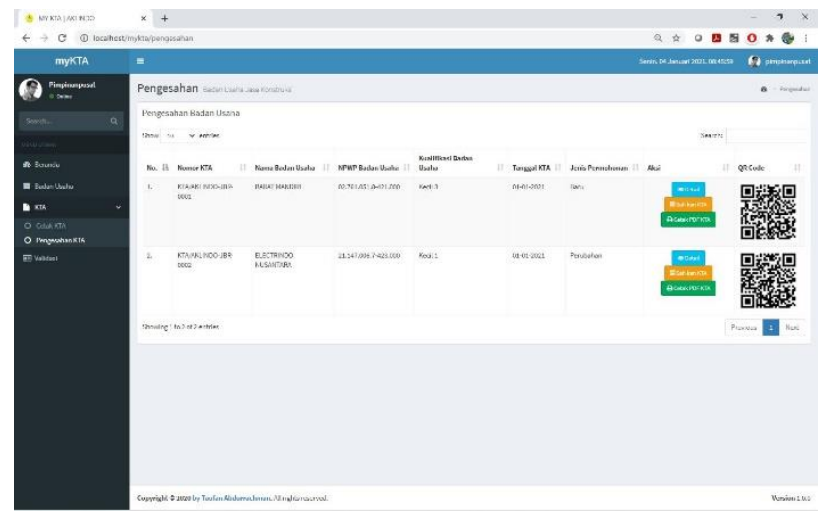

Gambar 18. Halaman Data Pengesahan KTA
Selanjutnya, untuk melakukan pengecekan validitas KTA dapat memanfaatkan $Q R$ Code sebagai representasi dari suatu tanda tangan yang disematkan pada setiap KTA. Gambar 19 menunjukan halaman untuk melakukan pengecekan validitas KTA.

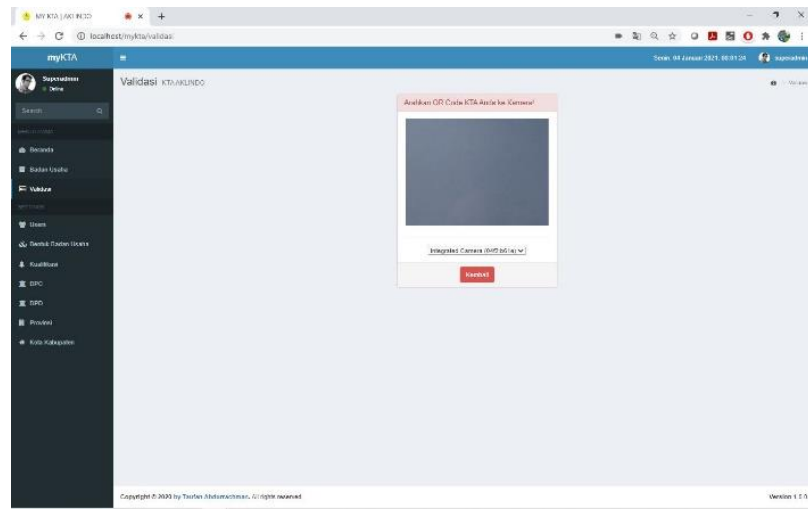

Gambar 19. Halaman Validasi KTA

\section{B. Pengujian dan Pembahasan}

Pada tahap pengujian aplikasi sistem informasi asosiasi AKLINDO ini, pengujian menggunakan metode black box testing secara lokal untuk menguji kesesuaian antara masukkan dan keluaran dari sistem, pengujian terhadap sistem yang telah dibangun hanya dilakukan terhadap fungsionalitas dari sistem tersebut. Hasil dari pengujian menggunakan metode black box dapat dilihat pada Tabel II, dari hasil pengujian dapat disimpulkan bahwa sistem informasi asosiasi AKLINDO dapat berjalan dengan baik. Keluaran dari setiap skenario pengujian untuk setiap fungsionalitas telah menghasilkan keluaran yang sesuai dengan yang diharapkan.

TABEL II

PENGUJIAN FungSiONALiTAS Sistem

\begin{tabular}{|c|c|c|c|c|c|}
\hline \multirow[b]{2}{*}{$\begin{array}{l}\mathbf{N} \\
\mathbf{0}\end{array}$} & \multirow{2}{*}{$\begin{array}{c}\text { Uji } \\
\text { Fungsional } \\
\text { itas }\end{array}$} & \multirow{2}{*}{$\begin{array}{c}\text { Skenario } \\
\text { Pengujian }\end{array}$} & \multirow{2}{*}{$\begin{array}{c}\text { Hasil yang } \\
\text { Diharapk } \\
\text { an }\end{array}$} & \multicolumn{2}{|c|}{ Kesimpulan } \\
\hline & & & & $\begin{array}{c}\text { Berha } \\
\text { sil }\end{array}$ & $\begin{array}{c}\text { Gag } \\
\text { al }\end{array}$ \\
\hline 1 & Login & $\begin{array}{l}\text { Login } \\
\text { dengan } \\
\text { username } \\
\text { dan } \\
\text { password } \\
\text { superadmi } \\
\mathrm{n}\end{array}$ & $\begin{array}{l}\text { Masuk ke } \\
\text { halaman } \\
\text { dashboard } \\
\text { superadmi } \\
\mathrm{n}\end{array}$ & V & \\
\hline & & $\begin{array}{l}\text { Login } \\
\text { dengan } \\
\text { username } \\
\text { dan } \\
\text { password } \\
\text { admin }\end{array}$ & $\begin{array}{l}\text { Masuk ke } \\
\text { halaman } \\
\text { dashboard } \\
\text { admin }\end{array}$ & V & \\
\hline & & $\begin{array}{l}\text { Login } \\
\text { dengan } \\
\text { username } \\
\text { dan } \\
\text { password }\end{array}$ & $\begin{array}{l}\text { Masuk ke } \\
\text { halaman } \\
\text { dashboard } \\
\text { pimpinanp } \\
\text { usat }\end{array}$ & V & \\
\hline
\end{tabular}




\begin{tabular}{|c|c|c|c|c|c|}
\hline \multirow{2}{*}{$\begin{array}{l}\mathbf{N} \\
\mathbf{o}\end{array}$} & \multirow{2}{*}{$\begin{array}{c}\text { Uji } \\
\begin{array}{c}\text { Fungsional } \\
\text { itas }\end{array} \\
\end{array}$} & \multirow{2}{*}{$\begin{array}{l}\text { Skenario } \\
\text { Pengujian }\end{array}$} & \multirow{2}{*}{$\begin{array}{c}\text { Hasil yang } \\
\text { Diharapk } \\
\text { an }\end{array}$} & \multicolumn{2}{|c|}{ Kesimpulan } \\
\hline & & & & $\begin{array}{c}\text { Berha } \\
\text { sil }\end{array}$ & $\begin{array}{c}\text { Gag } \\
\text { al }\end{array}$ \\
\hline & & $\begin{array}{l}\text { pimpinanp } \\
\text { usat }\end{array}$ & & & \\
\hline \multirow[t]{2}{*}{2} & User & $\begin{array}{l}\text { Tambah } \\
\text { user }\end{array}$ & $\begin{array}{l}\text { Masuk ke } \\
\text { halaman } \\
\text { tambah } \\
\text { user dan } \\
\text { data user } \\
\text { tersimpan } \\
\text { ke dalam } \\
\text { database }\end{array}$ & V & \\
\hline & & Hapus user & $\begin{array}{l}\text { Masuk ke } \\
\text { halaman } \\
\text { data user } \\
\text { dan data } \\
\text { user } \\
\text { terhapus } \\
\text { dari } \\
\text { database }\end{array}$ & V & \\
\hline \multirow[t]{2}{*}{3} & Kualifikasi & $\begin{array}{l}\text { Tambah } \\
\text { kualifikasi }\end{array}$ & $\begin{array}{l}\text { Masuk ke } \\
\text { halaman } \\
\text { tambah } \\
\text { kualifikasi } \\
\text { dan data } \\
\text { kualifikasi } \\
\text { tersimpan } \\
\text { ke dalam } \\
\text { database }\end{array}$ & V & \\
\hline & & $\begin{array}{l}\text { Hapus } \\
\text { kualifikasi }\end{array}$ & $\begin{array}{l}\text { Masuk ke } \\
\text { halaman } \\
\text { data } \\
\text { kualifikasi } \\
\text { dan data } \\
\text { kualifikasi } \\
\text { terhapus } \\
\text { dari } \\
\text { database }\end{array}$ & V & \\
\hline \multirow[t]{3}{*}{4} & $\begin{array}{l}\text { Badan } \\
\text { Usaha }\end{array}$ & $\begin{array}{l}\text { Tambah } \\
\text { badan } \\
\text { usaha }\end{array}$ & $\begin{array}{l}\text { Masuk ke } \\
\text { halaman } \\
\text { tambah } \\
\text { badan } \\
\text { usaha dan } \\
\text { data badan } \\
\text { usaha } \\
\text { tersimpan } \\
\text { ke dalam } \\
\text { database }\end{array}$ & V & \\
\hline & & $\begin{array}{l}\text { Ubah } \\
\text { badan } \\
\text { usaha }\end{array}$ & $\begin{array}{l}\text { Masuk ke } \\
\text { halaman } \\
\text { ubah badan } \\
\text { usaha dan } \\
\text { data badan } \\
\text { usaha } \\
\text { terbaru } \\
\text { tersimpan } \\
\text { ke dalam } \\
\text { database }\end{array}$ & V & \\
\hline & & $\begin{array}{l}\text { Hapus } \\
\text { badan } \\
\text { usaha }\end{array}$ & $\begin{array}{l}\text { Masuk ke } \\
\text { halaman } \\
\text { data badan }\end{array}$ & V & \\
\hline
\end{tabular}

\begin{tabular}{|c|c|c|c|c|c|}
\hline \multirow{2}{*}{$\begin{array}{l}\mathbf{N} \\
\mathbf{o}\end{array}$} & \multirow{2}{*}{$\begin{array}{c}\text { Uji } \\
\begin{array}{c}\text { Fungsional } \\
\text { itas }\end{array} \\
\end{array}$} & \multirow{2}{*}{$\begin{array}{c}\text { Skenario } \\
\text { Pengujian }\end{array}$} & \multirow{2}{*}{$\begin{array}{c}\text { Hasil yang } \\
\text { Diharapk } \\
\text { an }\end{array}$} & \multicolumn{2}{|c|}{ Kesimpulan } \\
\hline & & & & $\begin{array}{c}\text { Berha } \\
\text { sil }\end{array}$ & $\begin{array}{c}\text { Gag } \\
\text { al }\end{array}$ \\
\hline & & & $\begin{array}{l}\text { usaha dan } \\
\text { data badan } \\
\text { usaha } \\
\text { terhapus } \\
\text { dari } \\
\text { database }\end{array}$ & & \\
\hline & & $\begin{array}{l}\text { Detail } \\
\text { badan } \\
\text { usaha }\end{array}$ & $\begin{array}{l}\text { Masuk ke } \\
\text { halaman } \\
\text { detail } \\
\text { badan } \\
\text { usaha } \\
\end{array}$ & V & \\
\hline 5 & Cetak KTA & $\begin{array}{l}\text { Tambah } \\
\text { cetak KTA }\end{array}$ & $\begin{array}{l}\text { Masuk ke } \\
\text { halaman } \\
\text { tambah } \\
\text { cetak kta } \\
\text { dan data } \\
\text { cetak kta } \\
\text { tersimpan } \\
\text { ke dalam } \\
\text { database }\end{array}$ & V & \\
\hline & & $\begin{array}{l}\text { Ubah cetak } \\
\text { KTA }\end{array}$ & $\begin{array}{l}\text { Masuk ke } \\
\text { halaman } \\
\text { ubah cetak } \\
\text { kta dan } \\
\text { data cetak } \\
\text { kta terbaru } \\
\text { tersimpan } \\
\text { ke dalam } \\
\text { database }\end{array}$ & V & \\
\hline & & $\begin{array}{l}\text { Hapus } \\
\text { cetak KTA }\end{array}$ & $\begin{array}{l}\text { Masuk ke } \\
\text { halaman } \\
\text { data cetak } \\
\text { kta dan } \\
\text { data cetak } \\
\text { kta } \\
\text { terhapus } \\
\text { dari } \\
\text { database }\end{array}$ & V & \\
\hline & & $\begin{array}{l}\text { Export pdf } \\
\text { KTA }\end{array}$ & $\begin{array}{l}\text { Dokumen } \\
\text { digital } \\
\text { KTA siap } \\
\text { diunduh }\end{array}$ & V & \\
\hline 6 & Pengesahan & $\begin{array}{l}\text { Pengesaha } \\
\text { n KTA }\end{array}$ & $\begin{array}{l}\text { Masuk ke } \\
\text { halaman } \\
\text { pengesaha } \\
\text { n KTA dan } \\
Q R \text { Code } \\
\text { terbentuk }\end{array}$ & V & \\
\hline & & $\begin{array}{l}\text { Detail } \\
\text { KTA }\end{array}$ & $\begin{array}{l}\text { Masuk ke } \\
\text { halaman } \\
\text { detail KTA }\end{array}$ & V & \\
\hline 7 & Verifikasi & $\begin{array}{l}\text { Verifikasi } \\
\text { KTA }\end{array}$ & $\begin{array}{l}\text { Masuk ke } \\
\text { halaman } \\
\text { verifikasi } \\
\text { dan } \\
\text { mengakses } \\
\text { webcam/ } \\
\text { kamera } \\
\end{array}$ & V & \\
\hline
\end{tabular}


Pengujian selanjutnya yaitu pengujian enkripsi dan melihat response time yang diperlukan oleh sistem untuk melakukan proses enkripsi dan menghasilkan QR Code. Test Case yang digunakan pada pengujian ini dapat dilihat pada Tabel III.
TABEL III

Test CASE PENGUJiAn ENKRIPSi DAN RESPONSE TIME

\begin{tabular}{|l|l|}
\hline Plaintext & $\begin{array}{l}\text { diisi dengan nomor KTA AKLINDO } \\
\text { yang telah ditentukan untuk setiap } \\
\text { badan usaha sebagai } \text { input pengujian }\end{array}$ \\
\hline Key & namakuloaklindo2008 \\
\hline Metode & SHA256 dan AES 256 CBC \\
\hline
\end{tabular}

TABEL IV

PENGUJIAN ENKRIPSI DAN RESPONSE TIME

\begin{tabular}{|c|c|c|c|c|}
\hline $\begin{array}{c}\text { Uji } \\
\text { Kasus }\end{array}$ & Input Pengujian & Hasil Enkripsi & $\begin{array}{l}\text { Response } \\
\text { Time ( }(\mu \mathrm{s})\end{array}$ & $\begin{array}{l}\text { Hasil } Q R \\
\quad \text { Code }\end{array}$ \\
\hline 1 & $\begin{array}{l}\text { KTA/AKLINDO- } \\
\text { JBR-0001 }\end{array}$ & ZMc8DtMNZx3vgXiVgkZkBs0adX6wdZXgkESDeR5EU4Y= & 0,0000178 & 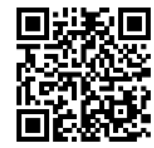 \\
\hline 2 & $\begin{array}{l}\text { KTA/AKLINDO- } \\
\text { JBR-0002 }\end{array}$ & ZMc8DtMNZx3vgXiVgkZkBgCguq0iDAlQ1kWbdAkQ/f4= & 0,0000219 & 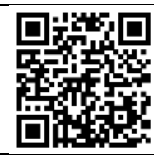 \\
\hline 3 & $\begin{array}{c}\text { KTA/AKLINDO- } \\
\text { JBR-0003 }\end{array}$ & ZMc8DtMNZx3vgXiVgkZkBs73/rBoqLoJZ96QM5PSiDI= & 0,0000169 & 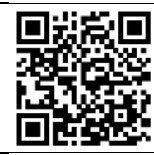 \\
\hline 4 & $\begin{array}{c}\text { KTA/AKLINDO- } \\
\text { JBR-0004 }\end{array}$ & ZMc8DtMNZx3vgXiVgkZkBk6JmUiluNdgiN+CUAZ1zl4= & 0,0000171 & 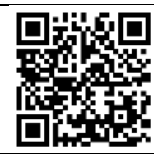 \\
\hline 5 & $\begin{array}{l}\text { KTA/AKLINDO- } \\
\text { JBR-0005 }\end{array}$ & ZMc8DtMNZx3vgXiVgkZkBgXSIpcCElcZAelS2jw6n2M= & 0,0000181 & 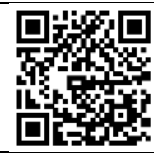 \\
\hline 6 & $\begin{array}{c}\text { KTA/AKLINDO- } \\
\text { JBR-0006 }\end{array}$ & ZMc8DtMNZx3vgXiVgkZkBkplth8i58gW+h8/Aqic3vc= & 0,0000190 & 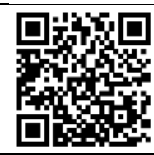 \\
\hline
\end{tabular}

Pada Tabel IV dapat dilihat hasil pengujian response time dan hasil pembentukan $Q R$ Code dengan menggunakan test case yang telah ditentukan.

Pada Tabel IV dapat dilihat bahwa ketika dilakukan pengujian secara lokal didapatkan response time kurang dari $0,00003 \mu s$ dan input pengujian dapat di enkripsi dengan baik menggunakan metode SHA-2 dan AES 256.

Selanjutnya melakukan pengujian avalanche effect yang dapat digunakan sebagai parameter pengujian untuk menganalisis tingkat keamanan pada algoritma kriptografi kunci simetris dan fungsi hash. Perubahan pada plaintext maupun pada key walaupun hanya 1 bit, akan menghasilkan perubahan yang signifikan pada hasil dari chipertext. Rumus untuk menghitung nilai avalanche effect menggunakan persamaan berikut ini[23]:

avalanche effect $=\frac{\text { jumlah perubahan bit }}{\text { jumlah seluruh bit awal }} \times 100 \%$
Avalanche effect yang bertujuan untuk membandingkan seberapa besar perubahan yang terjadi ketika plaintext berubah, sehingga dapat menilai tingkat efektifitas dari penerapan tanda tangan digital ini.

- Pengujian 1, melakukan perubahan 3 (tiga) karakter pada key, yaitu mengubah setiap karakter 'a' menjadi '@'. Hasil perubahan dan nilai avalanche effect dapat dilihat pada Tabel V.

TABEL V

Test Case dan Hasil Pengujian AVALANCHE EFFECT 1

\begin{tabular}{|l|l|}
\hline Plaintext awal & KTA/AKLINDO-JBR-0001 \\
\hline Key & namakuloaklindo2008 \\
\hline $\begin{array}{l}\text { Hasil enkripsi } \\
\text { plaintext } \text { awal }\end{array}$ & ZMc8DtMNZx3vgXiVgkZkBs0adX6wd \\
ZXgkESDeR5EU4Y=
\end{tabular}


- Pengujian 2, melakukan perubahan 2 (dua) karakter pada plaintext, yaitu mengubah setiap karakter 'A' menjadi 'a'. Hasil perubahan dan nilai avalanche effect dapat dilihat pada Tabel VI.

\section{TABEL VI}

Test Case dan Hasil Pengujian AVALANCHE EFFECT 2

\begin{tabular}{|l|l|}
\hline Plaintext awal & KTA/AKLINDO-JBR-0001 \\
\hline Key & namakuloaklindo2008 \\
\hline $\begin{array}{l}\text { Hasil enkripsi } \\
\text { plaintext awal }\end{array}$ & $\begin{array}{l}\text { ZMc8DtMNZx3vgXiVgkZkBs0adX6wd } \\
\text { ZXgkESDeR5EU4Y= }\end{array}$ \\
\hline $\begin{array}{l}\text { Perubahan } \\
\text { plaintext }\end{array}$ & $\mathrm{KTa/aKLIND0-JBR-0001}$ \\
\hline $\begin{array}{l}\text { Hasil perubahan } \\
\text { enkripsi } \text { plaintext }\end{array}$ & $\begin{array}{l}\text { Ijumn9iatHUrLTOv+INR/W6ODvoE/2ep } \\
\text { Xj3az6sL9q0= }\end{array}$ \\
\hline Perubahan bit & $138 \mathrm{bit}$ \\
\hline Avalanche effect & $39,2 \%$ \\
\hline
\end{tabular}

- Pengujian 3, melakukan perubahan 2 (dua) karakter pada key, yaitu mengubah setiap karakter ' $\mathrm{k}$ ' menjadi ' $\mathrm{X}$ '. Hasil perubahan dan nilai avalanche effect dapat dilihat pada Tabel VII.

TABEL VII

Test CASE DAN Hasil PENGUJian AVALANCHE EFFECT 3

\begin{tabular}{|l|l|}
\hline Plaintext awal & KTA/AKLINDO-JBR-0001 \\
\hline Key & namakuloaklindo2008 \\
\hline $\begin{array}{l}\text { Hasil enkripsi } \\
\text { plaintext awal }\end{array}$ & $\begin{array}{l}\text { ZMc8DtMNZx3vgXiVgkZkBs0adX6wd } \\
\text { ZXgkESDeR5EU4Y= }\end{array}$ \\
\hline Perubahan key & namaXuloaXlindo2008 \\
\hline $\begin{array}{l}\text { Hasil perubahan } \\
\text { enkripsi } \text { plaintext }\end{array}$ & $\begin{array}{l}\text { 7eRCh+tTRMCkhY3bJIvEU5HUAzOkV } \\
\text { OtwVzgNrOalQCk= }\end{array}$ \\
\hline Perubahan bit & $145 \mathrm{bit}$ \\
\hline Avalanche effect & $41,19 \%$ \\
\hline
\end{tabular}

- Pengujian 4, melakukan perubahan 4 (empat) karakter pada key, yaitu mengubah setiap karakter 'a' menjadi 'A' dan setiap karakter ' $\mathrm{k}$ ' menjadi ' $\mathrm{X}$ '. Hasil perubahan dan nilai avalanche effect dapat dilihat pada Tabel VIII.

TABEL VIII

Test Case dan Hasil Pengujian AVALANChe EFFECT 4

\begin{tabular}{|l|l|}
\hline Plaintext awal & KTA/AKLINDO-JBR-0001 \\
\hline Key & namakuloaklindo2008 \\
\hline $\begin{array}{l}\text { Hasil enkripsi } \\
\text { plaintext awal }\end{array}$ & $\begin{array}{l}\text { ZMc8DtMNZx3vgXiVgkZkBs0adX6wd } \\
\text { ZXgkESDeR5EU4Y= }\end{array}$ \\
\hline Perubahan key & nAmAXuloAXlindo2008 \\
\hline $\begin{array}{l}\text { Hasil perubahan } \\
\text { enkripsi } \text { plaintext }\end{array}$ & $\begin{array}{l}\text { SyLfNVgJkd4lp31CmeFP48GTR/U9Qm } \\
\text { 6/5thyERS7+jc= }\end{array}$ \\
\hline Perubahan bit & 157 bit \\
\hline Avalanche effect & $44,6 \%$ \\
\hline
\end{tabular}

Berdasarkan pengujian avalanche effect yang telah dilakukan, maka didapat nilai rata-rata avalanche effect sebesar 40,97\%. Dari nilai rata-rata avalanche effect yang didapat, besarnya perubahan yang terjadi pada plaintext dan key berpengaruh terhadap hasil chipertext dari proses enkripsi, maka algoritma AES cukup efektif digunakan tanda tangan digital pada KTA AKLINDO.

\section{SIMPULAN}

Berdasarkan pembahasan mengenai hasil implementasi, pengujian dan evaluasi yang telah dilakukan pada aplikasi sistem informasi asosiasi AKLINDO, maka disimpulkan bahwa prototipe aplikasi sistem informasi asosiasi AKLINDO dapat berjalan dengan baik. Metode keamanan padat KTA menggunakan metode AES dan SHA-2 dapat diimplementasikan dengan baik pada sistem dan telah dapat menghasilkan KTA yang dilengkapi dengan $Q R$ Code sebagai representasi dari tanda tangan digital. Response time dari sistem untuk melakukan 1 (satu) proses enkripsi memerlukan rata-rata waktu kurang dari $0,00003 \mu \mathrm{s}$ dan nilai rata-rata avalanche effect sebesar $40,97 \%$ yang menunjukan seberapa acak perubahan yang terjadi pada chipertext.

Saran untuk penelitian kedepannya terkait dengan penggunaan tanda tangan digital pada kartu tanda anggota asosiasi yang bergerak dalam bidang jasa konstruksi, yaitu: dapat melakukan penelitian lebih lanjut untuk menetukan algoritma kriptografi lain yang cocok untuk diterapkan pada sistem informasi asosiasi sebagai metode keamanan data pada KTA. Selin itu dapat ditemukan kombinasi algoritama kriptografi yang lebih baik untuk proses enkripsi dan dekripsi data, sehingga keamanan data anggota asosiasi jasa konstruksi lebih terjamin. Dan diharapkan pada pengembangan aplikasi sistem informasi asosiasi jasa konstruksi kedepannya perlu dilakukan penyesuaian, studi lebih lanjut, dan penambahan fitur-fitur lainnya

\section{UCAPAN TERIMA KASIH}

Terima kasih kepada Dewan Pengurus Daerah Asosiasi Kontraktor Ketenagalistrikan Indonesia Provinsi Jawa Barat yang telah memberikan kesempatan untuk melaksanakan dan menyediakan data pada penelitian Tesis ini.

\section{DAFTAR PUSTAKA}

[1] Republik Indonesia, Undang-Undang Republik Indonesia Nomor 11 Tahun 2008 Tentang Informasi dan Transaksi Elektronik. Jakarta, 2008 .

[2] Pemerintah Republik Indonesia, Peraturan Pemerintah Republik Indonesia Nomor 82 Tahun 2012 Tentang Penyelenggaraan Sistem dan Transaksi Elektronik. Jakarta, 2012

[3] Pemerintah Indonesia, Undang-Undang Republik Indonesia Nomor 19 Tahun 2016 Tentang Perubahan Atas Undang-Undang Nomor 11 Tahun 2008 Tentang Informasi Dan Transaksi Elektronik. Jakarta, 2016.

[4] Pemerintah Republik Indonesia, Peraturan Pemerintah Republik Indonesia Nomor 71 Tahun 2019 Tentang Penyelenggaraan Sistem dan Transaksi Elektronik. Jakarta, 2019.

[5] Pemerintah Republik Indonesia, Peraturan Presiden Republik Indonesia Nomor 95 Tahun 2018 Tentang Sistem Pemerintahan Berbasis Elektronik. Jakarta, 2018.

[6] Pemerintah Republik Indonesia, Peraturan Pemerintah Republik Indonesia Nomor 24 Tahun 2018 Tentang Pelayanan Perizinan Berusaha Terintegrasi Secara Elektronik. Jakarta, 2018.

[7] Menteri Pekerjaan Umum dan Perumahan Rakyat, "Surat Edaran Nomor 06/SE/M/2019 Tentang Sertifikat Badan Usaha, Sertifikat Keahlian, dan Sertifikat Keterampilan Dalam Bentuk Elektronik," Jakarta, 2019. 
[8] Lembaga Pengembangan Jasa Konstruksi, “1241-

UM/LPJKN/IX/2020 tentang Pengembangan Sistem Informasi Terintegrasi pada Masing-Masing Asosiasi dengan SIKI LPJK,' 2020

[9] A. Irawan, A. Hasna, and R. Pahlevi, "Sistem Informasi Perdagangan Pada PT Yoltran Sari Menggunakan Php Berbasis Web,"Positif, vol. 1, no. 2, pp. 8-15, 2016.

[10] I. C. Sari, "Optimasi Pemodelan Enkripsi Data dengan Menggunakan Algoritma Kriptografi RSA sebagai Keamanan Data E-Mail," M. Kom. tesis, Universitas Sumatera Utara, 2020.

[11] N. W. Nasution, "Analisis Kinerja Rprime RSA dan Multi-Facto RSA Dalam Mengamankan Pesan," M. Kom. tesis, Universitas Sumatera Utara, 2019

[12] A. Hadi, "Rancang Bangun Sistem Pengamanan Dokumen Pada Sistem Informasi Akademik Menggunakan Digital Signature dengan Algoritma Kurva Eliptik," M. Si. tesis, Universitas Diponegoro, 2011.

[13] E. C. Prabowo and I. Afrianto, "Penerapan Digital Signature Dan Kriptografi Pada Otentikasi Sertifikat Tanah Digital," Komputa J. Ilm. Komput. dan Inform., vol. 6, no. 2, pp. 83-90, 2017, doi: 10.34010/komputa.v6i2.2481.

[14] H. Agung and Ferry, "Kriptografi Menggunakan Hybrid Cryptosystem dan Digital Signature," J. Tek. Inform. dan Sist. Inf., vol. 3, no. 1, pp. 34-45, 2016

[15] S. Setti, I. Gunawan, B. E. Damanik, S. Sumarno, and I. O. Kirana, "Implementasi Algoritma Advanced Encryption Standard dalam Pengamanan Data Penjualan Ramayana Department Store," JURIKOM (Jurnal Ris. Komputer), vol. 7, no. 1, p. 182, 2020, doi: 10.30865/jurikom.v7i1.1960.

[16] A. Prameshwari and N. P. Sastra, "Implementasi Algoritma Advanced Encryption Standard (AES) 128 Untuk Enkripsi dan
Dekripsi File Dokumen," Eksplora Inform., vol. 8, no. 2, p. 52, 2018, doi: 10.30864/eksplora.v8i1.139.

[17] A. S. Sukarno, "Pengembangan Aplikasi Pengamanan Dokumen Digital Memanfaatkan Algoritma Advance Encryption Standard, RSA Digital Signature dan Invisible Watermarking," in Seminar Nasional Aplikasi Teknologi Informasi (SNATI) 2013, 2013, pp. 1-8, ISSN:1907-5022.

[18] A. Singhal and R. S. Pavithr, "Degree Certificate Authentication using QR Code and Smartphone," Int. J. Comput. Appl., vol. 120 , no. 16 , pp. $38-43$, 2015, doi: $10.5120 / 21315-4303$.

[19] M. Warasart and P. Kuacharoen, "Paper-based Document Authentication using Digital Signature and QR Code," in $4 T H$ International Conference on Computer Engineering and Technology, 2012, vol. 40, no. January, pp. 94-98.

[20] A. G. P. Suratma and A. Azis, "Tanda Tangan Digital Menggunakan Qr Code Dengan Metode Advanced Encryption Standard," Techno, vol. 18, no. 1, pp. 59-68, 2017.

[21] Y. Anshori, A. Y. Erwin Dodu, and D. M. P. Wedananta, "Implementasi Algoritma Kriptografi Rivest Shamir Adleman (RSA) pada Tanda Tangan Digital," Techno.Com, vol. 18, no. 2, pp. 110-121, 2019, doi: 10.33633/tc.v18i2.2166.

[22] F. Nuraeni, Y. H. Agustin, D. Kurniadi, and I. D. Ariyanti, "Implementasi Skema QR-Code dan Digital Signature menggunakan Kombinasi Algoritma RSA dan AES untuk Pengamanan Data Sertifikat Elektronik," in Seminar Nasional Teknologi Informasi, Komunikasi dan Industri (SNTIKI) 12, 2020, pp. 43-52.

[23] Sugiyanto and R. K. Hapsari, "Pengembangan Algoritma Advanced Encryption Standard pada Sistem Keamanan SMS Berbasis Android Menggunakan Algoritma Vigenere," J. Ultim., vol. 8, no. 2, pp. 131-138, 2016, doi: 10.31937/ti.v8i2.528. 